\title{
Intensitas Serangan Hama Penggerek Batang Kakao di Perkebunan Rakyat Cipadang, Gedongtataan, Pesawaran
}

\section{(Cacao Stem Borer Intensity in Smallholder Cacao Plantation in Cipadang, Gedongtataan, Pesawaran)}

\author{
Puji Lestari ${ }^{1 *}$, Purnomo ${ }^{1)}$ \\ 1) Program Studi Proteksi Tanaman Fakultas Pertanian Universitas Lampung, Jl. Soemantri \\ Brodjonegoro No. 1 Gedung Meneng, Bandar Lampung, 35145 \\ E-mail: puji.lestari@fp.unila.ac.id
}

\begin{abstract}
Lampung is one of the Province that potential to cacao produce. Stem borer Zeuzera coffeae (Lepidoptera: Cossidae) is one of the pests that often be found, besides Conopomorpha cramerella and Helopelthis sp. Z. coffeae can bore branches and stems it caused xylem damage, plant break easily or plant growth inhibited. The research were conducted from September to October 2017. Sampling was doing at smallholder cocoa plantation in Cipadang Village, Gedongtataan Sub-district, Pesawaran District. Survey was doing to observe pest attacks characteristic, inventory of attacked host, identification of symptoms, and number of fruits. Attack intensity in young plant is higher than in older plants. In 4 years plants the intensity of attack and damage are 11,34\% and 7,73\%. While the intensity of attack and damage in the 9 plant years are 7,50\% and 5,00\%.
\end{abstract}

Keywords: attack intensity, cocoa, stem borer, Zeuzera sp.

DOI: http://dx.doi.org/10.25181/jaip.v6i1.746

Diterima: 13 Februari 2018 / Disetujui: 12 Mei 2018 / Diterbitkan: 17 Mei 2018

\section{PENDAHULUAN}

Indonesia adalah negara penghasil kakao terbesar ketiga dunia setelah Pantai Gading dan Ghana (Rubiyo \& Siswanto, 2012). Kakao juga merupakan komoditas perkebunan yang memiliki peran strategis sebagai sumber pendapatan masyarakat, memiliki prospek pasar yang baik di dalam maupun ekspor sehingga kakao dipilih sebagai komoditas yang perlu dikembangkan (Aisyah et al., 2016; Darmono et al., 2016). Provinsi Lampung adalah salah satu daerah yang berpotensi menjadi penghasil kakao. Berdasarkan data dari Direktorat Jenderal Perkebunan (2015) diketahui bahwa pada tahun 2014 pulau Sumatera menjadi peringkat kedua penghasil kakao terbesar setelah Sulawesi, dan Propinsi Lampung menjadi salah satu daerah dengan perkebunan kakao rakyat yang cukup besar yaitu 71.404 ha dari total luas perkebunan kakao yang ada 72.032 ha.

Jika dilihat dari produksinya, perkebunan kakao rakyat masih sangat rendah jika dibandingkan dengan perkebunan kakao milik swasta atau pemerintah. Perkebunan kakao rakyat di Provinsi Lampung dengan luas 71.404 ha hanya mampu memproduksi kakao 34.013 ton.tahun ${ }^{-1}$ sedangkan perkebunan kakao swaswa dengan luas area 600 ha mampu menghasilkan 645 ton.tahun ${ }^{-1}$. Demikian juga dengan perkebunan kakao yang dikelola oleh pemerintah dengan luas 
area 20 ha mampu menghasilkan 23 ton.tahun $^{-1}$ (Direktorat Jenderal Perkebunan, 2015). Hal ini menunjukkan bahwa kebun kakao rakyat belum dikelola dengan baik, sehingga berbagai masalah terutama hama dan penyakit tanaman harus dihadapi oleh petani.

Penggerek batang kakao Zeuzera coffeae (Lepidoptera: Cossidae) merupakan salah satu hama yang sering dihadapi oleh petani, disamping penggerek buah dan penghisap buah kakao. Ulat Z. coffeae dapat menggerek cabang bahkan batang pokok tanaman dengan menggerek bagian empelur (xylem) (Agussalim, 2008; Panthi et al., 2009; Sutrisno, 2015) sehingga menyebabkan tanaman mudah patah atau pertumbuhan tanaman menjadi terhambat. Jika menyerang cabang muda, tanaman dapat pulih setelah ulat keluar dari batang (Agussalim, 2008), jika menyerang batang utama tanaman sulit untuk kembali pulih. Serangan hama ini mengakibatkan pengakutan hara dari dalam tanah ke seluruh bagian tanaman terganggu.

Serangan hama ulat penggerek batang dapat diidentifikasi melalui adanya liang gerekan pada batang disertai dengan adanya kotoran berbentuk silindrik dan berwarna merah kehitamhitaman yang keluar dari liang gerekan. Pada serangan yang berat, Zeuzera coffeae dapat mengakibatkan patahnya cabang, kematian bagi tanaman muda, dan mengelupasnya kulit batang pada tanaman. Kondisi ini jelas menimbulkan masalah terutrama produksi buah, mengingat bahwa bunga kakao tumbuh di bagian batang (cauliflorous).

Berbagai faktor dapat mempengaruhi meningkatnya perkembangan hama yaitu pola tanam dengan jarak tanam yang rapat, jumlah naungan yang banyak, sanitasi (pemangkasan) kurang baik dan penggunaan pestisida yang kurang bijaksan. Zeuzera coffeae serangga yang bersifat nocturnal atau aktif dimalam hari, ngengat aktif meletakkan telur pada malam hari. Pada siang hari, ngengat Z. coffeae bersembunyi di tempat yang terlindung dari sinar matahari. Cara budidaya atau perawatan yang kurang tepat pemeliharaan yang kurang baik dapat memicu perkembangan hama ini, misalnya pada proses panen yang tidak hati-hati sehingga kulit batang tanaman kakao terkelupas atau luka. Z. coffeae meletakkan telur pada celah kulit kayu (Agussalim, 2008).

Belum ada informasi mengenai intensitas serangan $Z$. coffeae pada tanaman kakao. Pada tanaman jati diketahui intensitas kerusakan mencapai 5,2\% pada tanaman berumur 11 bulan (Herdiana, 2010). Pada tanaman Lada persentase serangan hama ini dilaporkan sebesar $80 \%$ pada tanaman umur 2 tahun dan 60\% pada tanaman umur 3 tahun. Persen serangan menurun dengan bertambahnya umur tanaman (Prat \& Haneda, 1999). Oleh karena itu, pengamatan hama ini secara rutin perlu dilakukan untuk mencegah meluasnya serangan pada perkebunan kakao rakyat di Desa Cipadang, Kecamatan Gedong Tataan. Penelitian ini bertujuan untuk mengetahui: intensitas serangan hama penggerek batang kakao pada perkebunan kakao rakyat Cipadang, Gedongtataan, Pesawaran dan hubungan antara kerusakan batang dengan jumlah buah kakao. 


\section{METODE PENELITIAN}

Kegiatan penelitian dilaksanakan pada September sampai dengan Oktober 2017. Pengambilan sampel dilakukan di perkebunan kakao rakyat di Desa Cipadang, Kecamatan Gedongtataan, Kabupaten Pesawaran.Alat dan bahan yang digunakan dalam penelitian ini adalah pertanaman kakao, alat tulis, kamera digital, meteran, gergaji dan golok, botol vial, alkohol 70\%.

Kegiatan survey lapangan dilakukan meliputi pengamatan terhadap karakteristik serangan hama, inventarisasi inang terserang, identifikasi gejala, dan jumlah buah. Kegiatan pengamatan dilakukan terhadap semua individu pohon yang ada di lokasi (sensus). Kegiatan identifikasi jenis hama yang diperoleh dilakukan di laboratorium. Pengamatan terhadap individu pohon yang terserang dilakuan untuk mengetahui intensitas kerusakan hama penggerek batang. Variabel yang diukur meliputi jumlah lubang gerek dan kondisi tajuk. Pengamatan dilakukan pada dua lokasi kebun kakao, masing-masing kebun terdiri dari 120 tanaman dan 97 tanaman.

Pada saat pelaksanaan sensus, jika ditemukan tanaman bergejala penggerek batang maka dihitung jumlah liang gerek dari bagian luar. Penghitungan liang gerek didasarkan pada lubang di bagian permukaan batang dan ditandai dengan adanya kotoran silindrik berwarna kemerahan. Batang bergejala tersebut kemudian dipotong dengan menggunakan gergaji. Hasil potongan batang/cabang bergejala kemudian dibelah dengan menggunakan golok atau parang. Kemudian diukur panjang liang gerek yang disebabkan oleh Zeuzera coffeae. Hama penggerek yang ditemukan kemudian dikoleksi dalam botol vial yang berisi alkohol 70\%. Sampel hama penggerek diidentifikasi untuk memastikan bahwa hama tersebut adalah Zeuzera coffeae.

\section{Analisis Data}

Untuk mengetahui intensitas serangan, data jumlah pohon terserang dianalisis dengan menggunakan rumus:

$$
I=\frac{n}{N} \times 100 \%
$$

$$
\begin{aligned}
\text { dengan } \mathrm{I} & =\text { Intensitas serangan }(\%) \\
\mathrm{n} & =\text { Jumah tanaman yang terserang } \\
\mathrm{N} & =\text { Jumlah seluruh tanaman }
\end{aligned}
$$

Tanaman kakao yang terserang Zeuzera coffeae tidak langsung mengalami kerusakan mutlak, sehingga perlu dihitung intensitas kerusakan tanaman. Intensitas kerusakan tanaman dihitung berdasarkan keparahan tanaman terserang, berdasarkan kategori skor sebagai berikut:

Skor 0: tanaman sehat tanpa gejala serangan hama

1: kerusakan 1-25\% (kerusakan rendah, liang gerak 1 pada cabang)

2: kerusakan 26-50\% (kerusakan sedang, liang gerek 2 pada cabang)

3: kerusakan $51-75 \%$ (kerusakan berat, liang gerek $\geq 3$ pada cabang) 
4: kerusakan $>75 \%$ (sangat berat, menyerang batang utama)

Intensitas kerusakan dapat dihitung berdasarkan rumus:

$$
I K=\frac{\sum(\operatorname{mix} w i)}{Z x N} \times 100 \%
$$

dengan IK = Intensitas kerusakan

$$
\begin{aligned}
& \mathrm{n}=\text { jumlah jaringan tanaman yang terserang pada setiap kategori (skor) } \\
& \mathrm{v}=\text { kategori (skor) serangan } \\
& \mathrm{Z} \text { = kategori serangan tertinggi } \\
& \mathrm{N}=\text { jumlah total jaringan yang diamati }
\end{aligned}
$$

Untuk mengetahui pengaruh atau hubungan kerusakan batang tanaman terhadap jumlah buah yang dihasilkan, data jumlah buah dan intensitas kerusakan dianalisis dengan menggunakan uji korelasi menggunakan rumus:

$$
r=\frac{n \sum x y-\left(\sum x\right)\left(\sum y\right.}{\sqrt{\left(n \sum x^{2}-\left(\sum x\right)^{2}\right)\left(n \sum y^{2}-\left(\sum y\right)^{2}\right)}}
$$

Dengan $\mathrm{n}$ = banyaknya pasangan data $\mathrm{X}$ dan $\mathrm{Y}$

$$
\sum \mathrm{x}=\text { total jumlah dari variabel } \mathrm{X}
$$

$\sum \mathrm{y}=$ total jumlah variabel $\mathrm{Y}$

$\sum \mathrm{x}^{2}=$ kuadrat total jumlah variabel $\mathrm{X}$

$\sum \mathrm{y}^{2}=$ kuadrat total jumlah variabel $\mathrm{Y}$

$\sum x y=$ Hasil perkalian dari total jumlah variabel $\mathrm{X}$ dan Variabel $\mathrm{Y}$

Koefisien korelasi diuji dengan uji t korelasi dengan nilai $\alpha 0,05$.

\section{HASIL DAN PEMBAHASAN}

\section{Identifikasi Serangga Penyebab Kerusakan}

Dari pengamatan yang telah dilakukan, dapat dipastikan bahwa kerusakan batang terjadi akibat serangan hama penggerek batang kakao Zeuzera coffeae (Gambar 1). Penggerek batang Zeuzera coffeae diketahui hanya menyerang tanaman atau batang muda (Siswanto \& Karmawati, 2012). Pada tanaman jati, penggerek $Z$. coffeae menyerang cabang-cabang jati muda dan bagian pucuk tanaman jati (Herdiana, 2010). Zeuzera coffeae disebut juga penggerek cabang merah, hal ini karena larva berwarna kemerahan. 


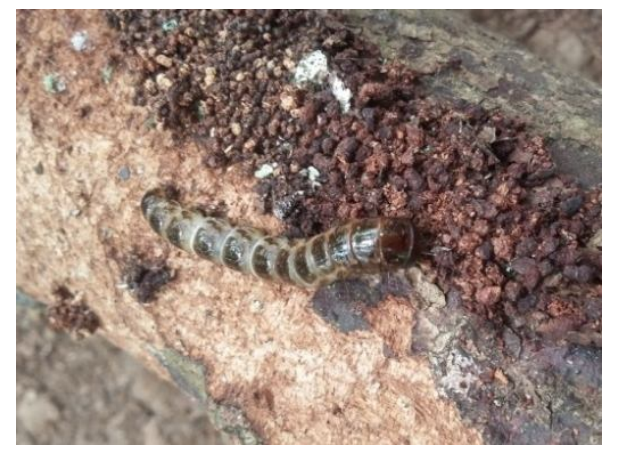

Gambar 1. Larva penggerek batang kakao Zeuzera coffeae

\section{Gejala Kerusakan pada Tanaman Inang}

Hama ini menyerang cabang muda dan juga batang pohon. Tanaman yang terserang Zeuzera coffeae menunjukkan gejala terdapat liang gerek di permukaan batang. Ulat hama ini merusak bagian batang/cabang dengan cara menggerek menuju empelur (xylem) batang/cabang (Gambar 2). Selanjutnya gerekan membelok ke arah atas. Hama ini menyerang tanaman muda. Pada permukaan lubang yang baru digerek sering terdapat campuran kotoran dengan serpihan jaringan. Akibat gerekan ulat, bagian tanaman di atas lubang gerekan akan merana, layu, kering dan mati.

Pada intensitas kerusakan parah, terlihat gejala hilangnya lapisan permukaan kulit (Gambar 3). Kondisi ini dapat mengakibatkan produksi buah menurun. Hal ini karena kakao merupakan tanaman yang berbuah pada batang (cauliflorous). Dari hasil pengamatan gejala serangan, hama penggerek $Z$. coffeae tidak hanya menyerang tanaman muda tetapi juga menyerang tanaman yang berumur 9 tahun. Pada kerusakan parah terlihat hampir seluruh bagian kulit batang kakao hilang. Hilangnya lapisan kulit ini diduga akibat aktivitas makan dari Z. coffeae. Asumsi ini diperkuat dengan ditemukannya beberapa larva yang berda di permukaan batang, tersembunyi di bawah kotoran silindrik. Kotoran tersebut memiliki alur membentuk lorong pada permukaan kulit batang. Di lain hal, jika batang dibelah liang gerek yang ditemukan hanya sepanjang ukuran larva (Gambar 3). Larva akan berpupa di dalam liang gerek dalam batang (Gambar 3).
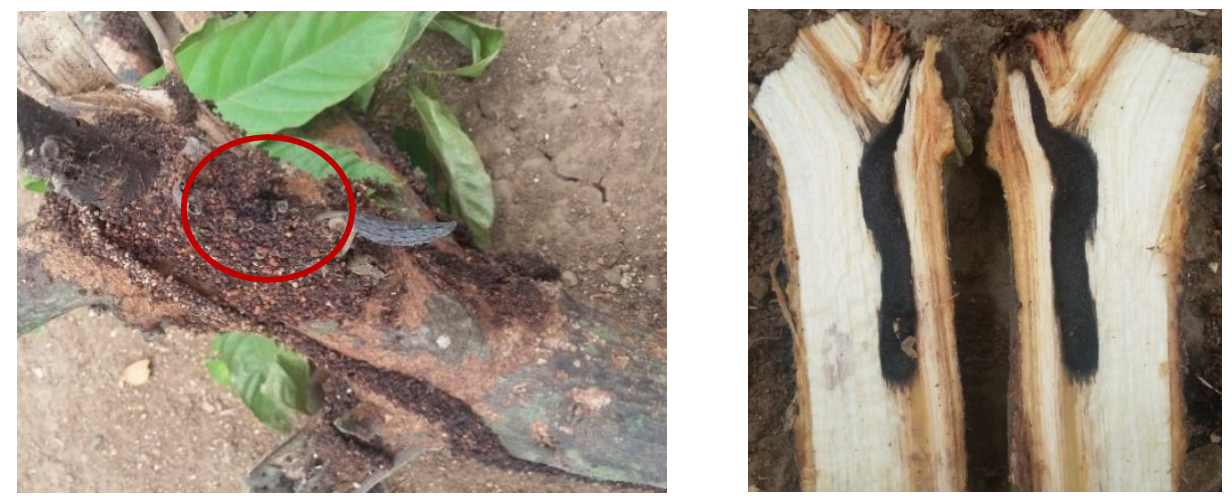

Gambar 2. Gejala serangan penggerek batang kakao Zeuzera coffeae; A. Lubang gerek Zeuzera coffeae; B. Liang gerek pada batang yang terserang Zeuzera coffeae. 

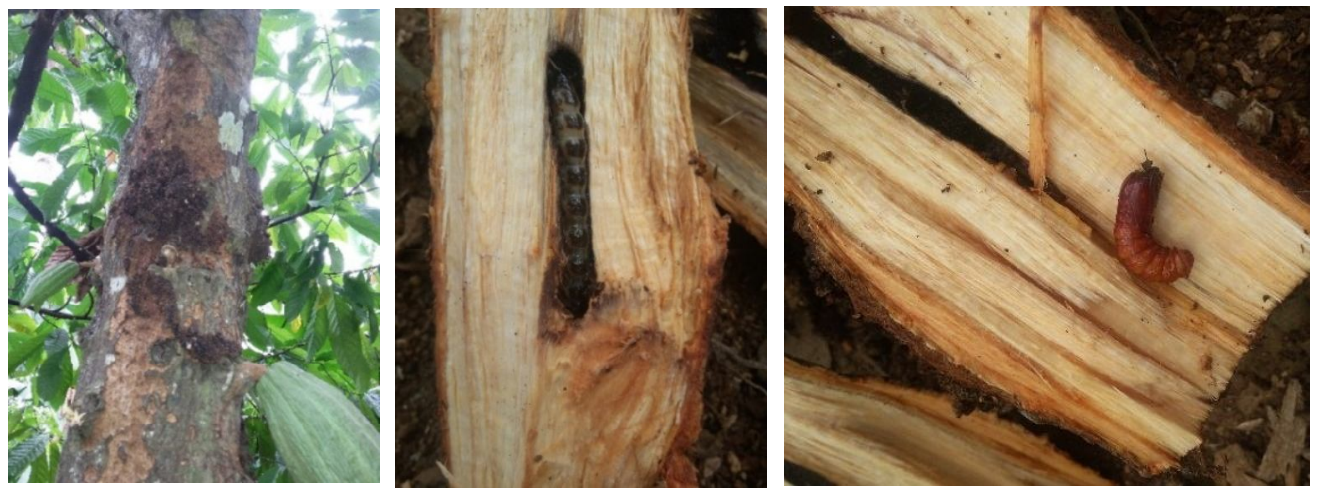

Gambar 3. a. Kerusakan permukaan batang akibat Z. coffeae; b. Larva Z. coffeaedalam liang gerek; c. Pupa Z. coffeae

\section{Intensitas Serangan Zeuzera coffeae dan Intensitas Kerusakan Batang Kakao}

Hasil pengamatan menunjukkan bahwa intensitas serangan Z. coffeae pada tanaman umur 4 tahun lebih tinggi dibandingkan dengan tanaman yang berumur 9 tahun. Baik persentase intensitas serangan maupun intensitas kerusakan lebih tinggi pada tanaman yang berumur 4 tahun. Pada tanaman umur 4 tahun intensitas serangan dan intensitas kerusakan berturut-turut 11,34\% dan 7,73\%. Sedangkan intensitas serangan dan intensitas kerusakan pada tanaman umur 9 tahun yaitu 7,50\% dan 5,00\% (Tabel 1). Hal ini mengindikasikan bahwa Z. coffeae lebih menyukai tanaman yang muda. Menurut Prat \& Haneda (1999) pada tanaman Eucalyptus deglupta hama penggerek batang $Z$. coffeae menyerang pada tanaman berusia 2-3 tahun. Pada tanaman jati, penggerek $Z$. coffeae menyerang cabang-cabang jati muda dan bagian pucuk tanaman jati (Herdiana, 2010).

Tabel 1. Intensitas serangan dan intensitas kerusakan tanaman akibat serangan Z. coffeae

\begin{tabular}{|c|c|c|c|c|}
\hline \multirow{2}{*}{ Umur tanaman } & \multicolumn{2}{|c|}{ Jumlah pohon } & \multirow{2}{*}{$\begin{array}{c}\text { Intensitas } \\
\text { serangan }(\%)\end{array}$} & \multirow{2}{*}{$\begin{array}{c}\text { Intensitas } \\
\text { kerusakan (\%) }\end{array}$} \\
\hline & Sehat & Terserang Z. coffeae & & \\
\hline 9 tahun & 111 & 9 & 7,50 & 5,00 \\
\hline 4 tahun & 86 & 11 & 11,34 & 7,73 \\
\hline
\end{tabular}

Keberadaan hama penggerek batang kakao selama ini masih diabaikan, hal ini karena $Z$. coffeae bukan merupakan hama utama melainkan hanya hama minor. Hama minor merupakan jenis hama yang relatif kurang penting, karena kerusakan yang ditimbulkan masih dapat ditoleransi oleh tanaman (Suroto et al., 2013). Walaupun hanya bersifat sebagai hama minor, keberadaan Z. coffeae perlu diwaspadai karena terkadang populasinya meningkat melebihi aras toleransi ekonomik tanaman.

Keberadaan hama ini masih ditoleransi bahkan cenderung diabaikan oleh petani. Hal ini mungkin disebabkan oleh ketidaktahuan tentang teknik atau cara pengendalian, mengingat hama ini 
berada di dalam batang. Serangan pada batang muda maupun cabang dapat pulih jika serangga sudah keluar dari batang. Berdasarkan gejala yang teramati di lapang, keberadaan hama penggerek batang kakao perlu diwaspadai, karena hama ini tidak hanya menyerang bagian dalam batang, tetapi juga menyerang permukaan batang. Serangan Z. coffeae pada batang dapat berakibat pada penurunan produksi buah. Berdasarkan data yang diperoleh diketahui bahwa serangan hama ini dapat menurunkan jumlah buah (Tabel 2).

Tabel 2. Korelasi antara kerusakan tanaman dengan jumlah buah

\begin{tabular}{cccc}
\hline Umur tanaman & Koefisien korelasi & $\mathrm{t}$ korelasi & $\mathrm{t}$ tabel \\
\hline 9 tahun & $-0,263^{*}$ & 2,96 & 1,98 \\
4 tahun & $-0,359^{*}$ & 3,75 & 1,99 \\
\hline
\end{tabular}

Korelasi diuji dengan menggunakan uji t korelasi dengan nilai $\alpha 0,05$

Hasil analisis korelasi menunjukkan terdapat hubungan atau korelasi negatif antara kerusakan tanaman dengan jumlah buah. Pada tanaman umur 9 tahun nilai korelasi -0,263 lebih rendah dibandingkan dengan tanaman umur 4 tahun yaitu -0,359. Hal ini sejalan dengan intensitas kerusakan pada tanaman. Intensitas kerusakan pada tanaman umur 4 tahun lebih tinggi dibandingkan dengan tanaman umur 9 tahun. Demikian juga dengan intensitas kerusakan tanaman. Beberapa penelitian mengenai hama ini juga menunjukkan hasil yang sama, intensitas serangan pada tanaman muda lebih tinggi dibandingkan pada tanaman tua. Herdiana (2010) melaporkan intensitas serangan Z. coffeae pada tanaman jadi berumur 11 bulan mencapai 5,2\%, dan intensitas serangan akan mengalami penurunan seiring bertambahnya umur tanaman.

\section{KESIMPULAN}

Berdasarkan hasil pengamatan yang dilakukan, dapat disimpulkan bahwa intensitas serangan hama penggerek batang kakao $Z$. coffeae lebih tinggi pada tanaman muda. Serangan $Z$. coffeae pada tanaman kakao berakibat pada penurunan produksi buah kakao.

\section{DAFTAR PUSTAKA}

Aggussalim. (2008). Hama dan Penyakit Tanaman Kakao dan Cara Pengendaliannya. Buletin Teknologi dan Informasi Pertanian. Balai Pengkajian Teknologi Pertanian (BPTP) Sulawesi Tenggara.

Aisyah, S., Ma'arif, S., \& Arkerman, Y. (2016). Imitasi proses pemanfaatan limbah kakao pendukung strategi inovasi pengembangan produk hilir agroindustri kakao. Teknik industri, 4(3).

Darmono, T., Jamil, I., \& Santosa, D. A. (2016). Pengembangan penanda molekuler untuk deteksi Phytophthora palmivora pada tanaman kakao. E-Journal Menara Perkebunan, 74(2), 86-95. 
Ditjenbun. (2015). Kakao, Statistik Perkebunan Indonesia 2014-2016. Direktorat Jenderal Perkebunan. Kementerian Pertanian. Jakarta.

Herdiana, N. (2010). Potensi serangan hama tanaman jati rakyat dan upaya pengendaliannya di Rumpin, Bogor. Jurnal Penelitian Hutan Tanaman, 7(4), 177 - 185.

Panthi, B. B., Devkota, B., \& Devkota, J. U. (2009). Effect of botanical pesticides on soil fertility of coffee-orchards. Journal of Agriculture and Environment, 9, 16-22.

Prat, A.W. \& Haneda, N.F. (1999). Studi mekanisme toleransi leda (Eucaliptus deglupta Blume) terhadap hama penggerek batang (Zeuzera coffeae) untuk menunjang pemuliaan jenis. Jurnal Manajemen Hutan Tropika,5(1), 47-55.

Rubiyo, R., \& Siswanto, S. (2012). Peningkatan produksi dan pengembangan kakao (Theobroma cacao L.) di Indonesia. Jurnal Tanaman Industri dan Penyegar, 3(1), 33-48.

Siswanto \& Karmawati, L. (2012). Pengendalian hama utama kakao (Conopomorpha cramerella dan Helopeltis spp.) dengan pengendalian nabati dan agen hayati. Perspektif,11(2), 103-112.

Suroto, S., Kiswardianta, R. B., \& Utami, S. (2013). Identifikasi berbagai jenis hama padi (Oriza sativa) di Kecamatan Ngrayun Kabupaten Ponorogo sebagai sumber belajar siswa SMP kelas VIII semester gasal pokok bahasan hama dan penyakit. Jurnal Pendidikan, 19(1), 9-16.

Sutrisno, H. (2015). Molecular phylogeny of Indonesian Zeuzera (Lepidoptera: Cossidae) wood borer moths based on CO I gene sequence. Journal of Species Research, 4(1), 49-56. 